\title{
Создание биоцидных препаратов «Тефлекс»: от синтеза нового полимера до линейки продукции. Часть 2. Исследование влияния препаратов «Тефлекс» на свойства цементных композитов
}

\author{
В.Т.Ерофеев, МГУ им. Н.П.Огарева, Саранск \\ Д.А.Светлов, «Софт Протектор», Санкт-Петербург \\ В.Ф.Смирнов, ННГУ им. Н.И.Лобачевского, Н. Новгород \\ А.П.Федорцов, МГУ им. Н.П.Огарева, Саранск \\ С.В.Казначеев, МГУ им. Н.П.Огарева, Саранск \\ А.Д.Богатов, МГУ им. Н.П.Огарева, Саранск \\ А.И.Родин, МГУ им. Н.П.Огарева, Саранск \\ Л.А.Краева, НИИЭМ имени Пастера, С.-Петербург
}

Повреждения строительных материалов, вызванные ростом и развитием на них бактерий и мицелиальных грибов представляют серьёзную опасность как для конструкций зданий и сооружений, так и для здоровья людей. Один из эффективных способов устранения данных негативных факторов - это введение в их состав биоцидных добавок.

Приводятся результаты исследования свойств цементных композитов, содержащих в своем составе различные биоцидные препараты на основе гуанидиновой группировки (ПГМГ), которые выпускаются в РФ в промышленном масштабе под маркой «Тефлекс». При выполнении исследований рассматривались препараты марок: «Тефлекс Антиплесень», «Тефлекс Антисоль смывка», «Тефлекс Реставратор», «Тефлекс Защита для металла», «Тефлекс дезинфицирующий», «Тефлекс индустриальный». Показано, что применение биоцидных препаратов способствует снижению обрастаемости образцов цементных композитов мицелиальными грибами и проявление у них грибостойких и фунгицидных свойств.

С использованием метода рентгеноструктурного анализа выявлено, что при введении в составы соединений гуанидина изменяется количественное содержание минералов алита и белита. Исследованы цементные композиты, твердеющие как в нормальных температурно-влажностных условиях, так и подвергнутые термовлажностной обработке. Установлено, что введение всех рассмотренных добавок оказывает пластифицирующее действие и изменяет ряд других свойств. Прочность цементных композитов с добавками в количестве 3-5 мас. ч увеличивается. Приведены результаты исследования свойств композитов, наполненных кварцевыми порошками различной дисперсности и препаратом «Тефлекс». При этом наряду с однофракционными рассматривались многофракционные составы. Полученные результаты дают основание рекомендовать цемент-

1 Продолжение. Начало статьи «Создание биоцидных препаратов "Тефлекс": от синтеза нового полимера до линейки продукции. Часть 1. Разработка технологии получения биоцидных препаратов "Тефлекс"» см. в № 2 журнала «Academia. Архитектура и строительство» за 2020 год. ные композиции, содержащие добавки на основе гуанидина, для использования в зданиях и сооруженияхс биологическими средами. Приведены сведения о результатах использования цементных материалов и изделий в строительной отрасли.

Ключевые слова: долговечность конструкций, биоповреждения, микроорганизмы, защита от биоповреждений, биоцидные препараты «Тефлекс», цементные композиты, прочность, оптимизация состава.

Creation of Teflex Biocidal Preparations from the Synthesis of a New Polymer to the Product Line. Part

2. Study of the Effect of Teflex Preparations on the Properties of Cement Composites

V.T.Erofeev, Ogarev Mordovia State University, Saransk

D.A.Svetlov, "Soft Protector", St. Petersburg

V.F.Smirnov, UNN named after N.I.Lobachevsky, N. Novgorod A.P.Fedortsov, Ogarev Mordovia State University, Saransk

S.V.Kaznacheev, Ogarev Mordovia State University, Saransk

A.D.Bogatov, Ogarev Mordovia State University, Saransk

A.I.Rodin, Ogarev Mordovia State University, Saransk

L.A.Kraeva, Saint-Petersburg Pasteur Institute, St. Petersburg

Damages of building materials caused by the growth and development of bacteria and filamentous fungi on them are a serious danger both for the structures of buildings and for human health. One of the effective ways to eliminate these negative factors is the introduction of biocidal additives into their composition.

The results of the study of the properties of cement composites containing various biocidal preparations based on the guanidine group (PGMG), which are produced in the Russian Federation on an industrial scale under the Teflex brand, are presented. During the research, the following brands were considered: Teflex Antimold, Teflex Antisalt wash, Teflex Restorator, Teflex Protection for metal, Teflex disinfectant, Teflex industrial. It is shown that the use of biocidal preparations helps 
to reduce the overgrowth of samples of cement composites by filamentous fungi and the manifestation of fungi-resistant and fungicidal properties in them.

Using the method of X-ray diffraction analysis, it was revealed that the introduction of guanidine compounds into the composition of the compounds changes the quantitative content of the minerals alite and belite. Cement composites, which harden both under normal temperature and humidity conditions and have undergone thermalmoisture treatment, have been investigated. It was found that the introduction of all the considered additives has a plasticizing effect and changes several other properties. The strength of cement composites with additives in the amount of 3-5 wt. parts increases. The results of studying the properties of composites filled with quartz powders of various dispersion and the Teflex preparation are presented. In this case, along with single-fraction compositions, multi-fraction compositions were considered. The obtained results give grounds to recommend cement compositions containing additives based on guanidine for use in buildings and structures with biological media. The information on the results of using cement materials and products in the construction industry is given.

Keywords: durability of structures, biological damage, microorganisms, protection against biological damage, biocidal preparations "Teflex", cement composites, strength, composition optimization.

Повреждения строительных материалов, вызванные ростом и развитием на них бактерий и мицелиальных грибов, представляют серьёзную опасность как для конструкций зданий и сооружений, так и для здоровья людей. Одним из наиболее эффективных способов защиты строительных конструкций зданий и сооружений от поражений микроорганизмами является применение при изготовлении строительных материалов биоцидных добавок. Авторами на протяжении многих лет проводятся исследования биостойкости композиционных строительных материалов. К настоящему времени изучены механизмы биодеградации композитов на основе органических и неорганических связующих [1-8].

Большое количество экспериментальных исследований проведено с полимерными, цементными, гипсовыми и другими композитами, содержащими в своём составе биоцидные препа- раты на основе соединений гуанидина. По результатам работы получено девять патентов ${ }^{2}$ и написано более 50-ти статей.

В данной статье приводятся результаты исследования структуры, свойств и биостойкости цементных композитов, содержащих в своём составе различные биоцидные препараты марки «Тефлекс» на основе гуанидиновой группировки (ПГМГ). В качестве биоцидных добавок рассматривались препараты следующих видов: «Тефлекс Антиплесень», «Тефлекс Антисоль смывка», «Тефлекс Реставратор», «Тефлекс Защита для металла», «Тефлекс дезинфицирующий», «Тефлекс индустриальный».

Научная концепция конструирования биоцидного бетона состоит в обеспечении прочной, долговечной и не обрастаемой микроорганизмами цементной матрицы и бетона в целом. Технология бетона базируется на системах оптимального состава различного размерного уровня: цемент-наполнитель, цемент-наполнитель-заполнитель, - содержащих добавки полифункционального действия.

Цемент - вяжущее вещество, являющееся главным компонентом при производстве различных бетонов. В отечественной и мировой практике производится большое количество цементов, которые классифицируются по способу производства, области применения и т.д. Для изготовления бетонных и железобетонных изделий используются различные цементы - рядовые, быстротвердеющие, сульфатостойкие и т.д. Очевидно, что для изготовления цементных биоцидных композитов также могут быть использованы различные виды цементов, в том числе специальные. Из последних цементов следует выделить в отдельную группу биоцидные вяжущие вещества.

В цементные системы вводятся химические или минеральные добавки, способствующие улучшению подвижности, повышению плотности, прочности и долговечности благодаря более высокому качеству протекания реакций гидратации или других факторов. Например, золь-добавки, содержащие нанодисперсии, оказывают повышенное влияние на гидратационную активность цемента как за счёт диспергирования частиц цемента, так и за счёт каталитического воздействия на твердеющую систему с образованием повышенного количества преимущественно низкоосновных гидросиликатов [9]. В качестве минеральных добавок в цементных системах используются ультратонкие порошки: микрокремнезём, зола и др., а в качестве химических добавок - эффективные суперпластификаторы. Их совместное введение способствует

\footnotetext{
21. Полимербетонная смесь. Патент на изобретение № 2329228.

2. Гипсовая композиция. Патент на изобретение № 2377202.

3. Сырьевая смесь для изготовления крупнопористого бетона. Патент на изобретение №2621327.

4. Гипсоцементно-пуццолановая композиция. Патент на изобретение №2377203.

5. Цементная композиция. Патент на изобретение № 2368584.

6. Сырьевая смесь для изготовления крупнопористого бетона. Патент на изобретение № 2574746 .

7. Биоцидный препарат и способ биоцидной обработки поверхности. Патент на изобретение № 2287348.

8. Дезинфицирующее средство «Тефлекс». Патент на изобретение № 2287325.

9. Дезинфицирующее средство. Патент на изобретение № 2345794.
} 
снижению В/Ц-отношения. Частички микрокремнезёма или другого тонкозернистого материала, встраиваясь между частицами цемента, приводят к существенному повышению прочности. С учётом иерархии крупности различных зёрен формируются тонкозернистые, мелкозернистые и крупнозернистые цементные композиции. В работах [10; 11] разработаны компьютерные модели для уровня наноструктуры цементного камня, микро-, мезо- и макроструктуры бетона и методов расчёта их физико-механических характеристик.

Таким образом, проблема получения высококачественных бетонов решается путём использования при их изготовлении разнодисперсных высокоэффективных минеральных и химических модификаторов пролонгированного действия с синергетическим эффектом. Они обеспечивают многоуровневую модификацию дисперстногранулометрического состава и получение максимально плотной упаковки частиц и зёрен различных размеров с высоким уровнем концентрации твёрдой фазы в единице объёма, а также высокие показатели прочности и долговечности бетона. В отечественной и мировой практике по высококачественным бетонам накоплен значительный материал [12-16]. Например, В.И. Калашниковым в порошково-активированных бетонах в зависимости от крупности частиц зёрен дисперсной фазы выделены для изучения матрицы первого, второго и третьего рода. В данные системы могут быть встроены различные добавки и, что очень важно, различного размерного уровня: от нано- до макроуровня.

При проведении настоящих исследований ставилась задача выявления влияния биоцидных препаратов на свойства различных систем. В первом случае рассмотрение вопроса шло в рамках получения биоцидного цемента. В другом случае являлось целесообразным рассмотрение композитов с кварцевым наполнителем различной крупности при различном их содержании. В третьем - важным было рассмотрение композиций, содержащих одновременно в своём составе наполнители различного гранулометрического состава.

Технология получения биоцидных цементов описана в патентах ${ }^{3}$. Механизмы действия различных добавок при гидратации цементных систем определяются их селективным влиянием на адсорбцию, гидратообразование и т.д. Влияние добавок на цементные системы можно проследить уже на ранних стадиях гидратации по скорости тепловыделения и количеству теплоты, выделяющейся в системе [15]. Для этого используется комплекс физико-химических методов исследования, включающий калориметрию, рентгенофазовый, дифференциально-термический, ИК-спектроскопический, микроскопический и химический методы анализа [15-19 и др.]. В настоящих исследованиях приводятся результаты по установлению технических свойств разработанных биоцидных вяжущих. Биоцидный цемент имеет в своём составе (в процентном отношении): портландцементный клинкер - 93,5; двуводный гипс - 5,6; ПГМГ-С - 0,9.

3 1. Биоцидный портландцемент. Патент на изобретение RU 2491239.

2. Биоцидный портландцемент. Патент на изобретение RU 2491240.
Зарегистрированные параметры тепловыделения при гидратации образцов рядового (1) и биоцидного (2) цементов приведены на рисунке 1.

Согласно данным, отражённым на рисунке 1, первый пик в ранние часы гидратации характерен наложению экзотермических эффектов, происходящих при смачивании зёрен цемента, реакции образования эттрингита и иных AFt-фаз, а в отдельных случаях - и образованию гипса из полугидрата, появившегося в результате помола цемента. На рисунке 16 данный эффект не учитывался с целью выявления последующей гидратации основных фаз клинкера.

Второй пик соответствует реакциям образования $\mathrm{C}-\mathrm{S}-\mathrm{H}$ геля и гидроксида кальция, то есть начинается схватывание цементного теста. Установлено, что интенсивность начальных тепловых потоков при гидратации образцов биоцидного цемента меньше в сравнении с рядовым вяжущим, а в поздние периоды гидратации больше. Это говорит о более спокойном протекании процессов твердения биоцидного портландцемента по сравнению с рядовым составом.

Третий пик, характеризующий образование эттрингита, для рядового портландцемента, зафиксирован после 18 часов гидратации. Для биоцидного состава данный пик практически отсутствует.

Согласно данным суммарной тепловой энергии (см. рис. 1 б), после трёх суток твердения портландцементов наибольшая степень гидратации отмечена у контрольного состава. Также установлено ускорение процессов гидратации после первых суток твердения у состава с биоцидной добавкой в сравнении с контрольным составом. Вероятнее всего, замедление тепловыделения в первые сутки связано с негативным действием органической добавки, блокирующей реакцию.

На первом этапе разработки биоцидных цементных композитов были проведены исследования, установившие снижение обрастаемости образцов мицелиальными грибами и проявление у них грибостойких и фунгицидных свойств. В качестве вяжущего при изготовлении составов использовался бездобавочный портландцемент М500 0А0 «Мордовцемент», а в качестве добавок - «Тефлексы» различных видов. Исследование биологического сопротивления цементных составов, модифицированных биоцидными добавками, проводилось в соответствии с ГОСТ 9.049-91 (метод 1 и метод 3). Результаты испытаний приведены в табл. 1.
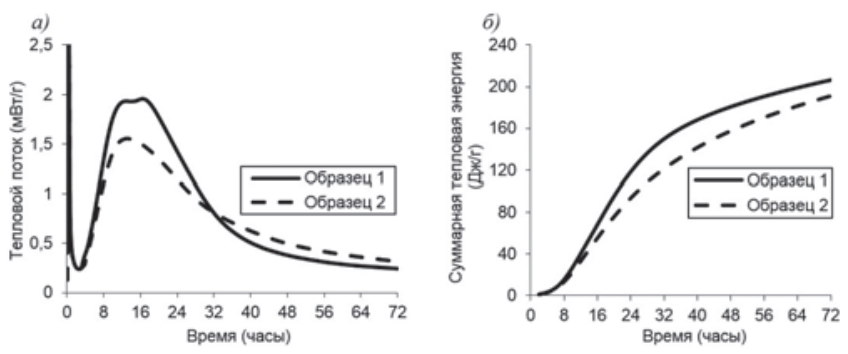

Рис. 1. Скорость тепловыделения (а) и суммарное количество выделившейся теплоты (б) при гидратации образцов рядового (1) и биоцидного (2) цементов 
Анализ результатов исследований композитов с добавками показывает, что введение в их состав всех использованных препаратов в концентрации $\geqslant 1$ мас. ч. придаёт им грибостойкость и соответственно подтверждает биоцидные свойства химических соединений на основе гуанидина. В результате осмотра композитов под микроскопом у составов, содержащих «Тефлекс Антиплесень» и «Тефлекс Реставратор» в количестве $\geqslant 3$ мас. ч., после выдержки в среде, заражённой спорами плесневых грибов, в условиях, оптимальных для их развития без дополнительных источников углеродного и минерального питания, рост грибов не был обнаружен. Введение препарата «Тефлекс Защита для металла» в количестве

Таблица 1. Влияние добавок на основе гуанидина на биостойкость цементных материалов

\begin{tabular}{|c|c|c|c|}
\hline \multirow{2}{*}{$\begin{array}{c}\text { Содержание } \\
\text { добавки, } \\
\text { мас. ч. }\end{array}$} & \multicolumn{2}{|c|}{$\begin{array}{c}\text { Устойчивость к действию } \\
\text { грибов, баллы }\end{array}$} & \multirow{2}{*}{$\begin{array}{c}\text { Характеристика } \\
\text { по ГОСТ 9.049-91 }\end{array}$} \\
\hline & Метод 1 & Метод 3 & \\
\hline \multicolumn{4}{|c|}{ Контрольный (бездобавочный) состав } \\
\hline- & 3 & 4 & Негрибостоек \\
\hline \multicolumn{4}{|c|}{ C препаратом «Тефлекс Антиплесень» } \\
\hline 1,0 & 1 & 4 & Грибостоек \\
\hline 3,0 & 0 & 4 & Грибостоек \\
\hline 5,0 & 0 & 4 & Грибостоек \\
\hline 7,5 & 0 & 4 & Грибостоек \\
\hline \multicolumn{4}{|c|}{ С препаратом «Тефрлекс Антисоль смывка» } \\
\hline 3,0 & 1 & 4 & Грибостоек \\
\hline 5,0 & 0 & 4 & Грибостоек \\
\hline 7,5 & 0 & 4 & Грибостоек \\
\hline \multicolumn{4}{|c|}{ С препаратом «Тефлекс Реставратор» } \\
\hline 1,0 & 1 & 4 & Грибостоек \\
\hline 3,0 & 0 & 3 & Грибостоек \\
\hline 5,0 & 0 & 3 & Грибостоек \\
\hline 7,5 & 0 & 3 & Грибостоек \\
\hline \multicolumn{4}{|c|}{ C препаратом «Тефлекс Защита для металла» } \\
\hline 1,0 & 1 & 4 & Грибостоек \\
\hline 3,0 & 0 & 3 & Грибостоек \\
\hline 5,0 & 0 & 2 & Грибостоек \\
\hline 7,5 & 0 & 0 & Фунгициден \\
\hline \multicolumn{4}{|c|}{ C препаратом «Тефлекс дезинфицирующий» } \\
\hline 1,0 & 0 & $0(0)^{*}$ & Фунгициден \\
\hline 3,0 & 0 & $0(4)$ & Фунгициден \\
\hline 5,0 & 0 & $0(4)$ & Фунгициден \\
\hline 7,5 & 0 & $0(4)$ & Фунгициден \\
\hline \multicolumn{4}{|c|}{ С препаратом «Тефлекс индустриальный» } \\
\hline 1,0 & 0 & $0(4)$ & Фунгициден \\
\hline 3,0 & 0 & $0(10)$ & Фунгициден \\
\hline 5,0 & 0 & $0(13)$ & Фунгициден \\
\hline 7,5 & 0 & $0(15)$ & Фунгициден \\
\hline
\end{tabular}

* В скобках приведён радиус зоны ингибирования роста мицелиальных грибов R, мм. $\geqslant 7,5$ мас. ч. способствует достижению фунгицидных свойств (вокруг образцов при испытании на питательной среде наблюдается зона отсутствия роста грибов). Использование же препаратов «Тефлекс дезинфицирующий» и «Тефлекс индустриальный» придаёт получаемому цементному камню фунгицидные свойства уже при введении 1 мас. ч. При этом при введении добавки «Тефлекс дезинфицирующий» в количестве $\geqslant 3$ мас. ч. возникает постоянная зона ингибирования роста грибов радиусом 4 мм. При введении добавки «Тефлекс индустриальный» в количестве 1 мас. ч. также достигается зона ингибирования роста грибов радиусом 4 мм, а с ростом количества вводимого препарата она постепенно увеличивается и при 7,5 мас. ч. составляет более 15 мм.

С целью экспериментального исследования процессов, происходящих в композитах с биоцидными добавками на основе гуанидина, были проведены исследования процессов их структурообразования с использованием метода рентгеноструктурного анализа. Данные исследования позволили установить определённые изменения в процессах их структурообразования.

В качестве контролируемых показателей при исследовании физико-механических свойств цементных композитов, содержащих изучаемые биоцидные добавки, рассматривались: изменение сроков схватывания, соотношение твёрдых и жидких компонентов, необходимое для создания цементного теста нормальной густоты, а также средняя плотность, прочность и водопоглощение затвердевших композитов. Установлено, что материалы по указанным свойствам удовлетворяют требованиям нормативных документов [7].

Выявлено, что введение всех рассмотренных добавок оказывает пластифицирующее действие. При этом наибольший пластифицирующий эффект достигается при применении препаратов «Тефлекс Антиплесень» и «Тефлекс Антисоль смывка».

Важным являлось установление оптимальных режимов отверждения композитов, модифицированных биоцидными препаратами на основе гуанидина. Объектами исследования на данном этапе были цементные композиты, твердеющие в нормальных температурно-влажностных условиях и подвергнутые термовлажностной обработке. При испытании по первому варианту группа образцов по истечении 7, 14 и 28 суток твердения в нормальных условиях подвергалась испытанию на прочность при сжатии. По второму варианту образцы в течение одних суток твердели при нормальных условиях, а затем в условиях термовлажностной обработки по режиму $1,5+6+2$ ч с температурой изотермического цикла $90{ }^{\circ} \mathrm{C}$. Результаты испытаний образцов по истечении 28 суток твердения в нормальных условиях приведены на рисунке 2 .

Для образцов, отверждённых в нормальных температурно-влажностных условиях, получены результаты, свидетельствующие о том, что при введении препаратов «Тефлекс 
Антиплесень», «Тефлекс Реставратор» и «Тефлекс индустриальный» прочность цементных композитов увеличивается, при этом максимум достигается при введении их в количестве 3-5 мас. 4.

На 28-е сутки твердения максимальная прочность выявлена у состава, содержащего 3 мас. ч. добавки «Тефлекс Реставратор» (превышение прочности по сравнению с контрольными образцами составила 27,5\%).

Значительную роль в цементных композитах играют наполнители и заполнители. С целью исследования свойств композитов, наполненных однофракционными наполнителями, в цементные пасты вводились кварцевые пески различной дисперсности (<0,16, 0,16-0,315, 0,315-0,63 мм) в количестве от 100 до 300 мас. ч. на 100 мас. ч. вяжущего. Исследования проведены с применением методов математического планирования эксперимента. В качестве матрицы планирования использовали план Коно, состоящий из девяти опытов. Варьируемыми факторами служили: $X_{1}$ - фракция наполнителя; $X_{2}$ - содержание наполнителя.

После проведения статистической обработки результатов эксперимента были получены уравнения регрессии, которые были проверены на адекватность по F-критерию Фишера. Полученные расчётные значения F-критерия показали более низкие значения по сравнению с табличными при 95-про-
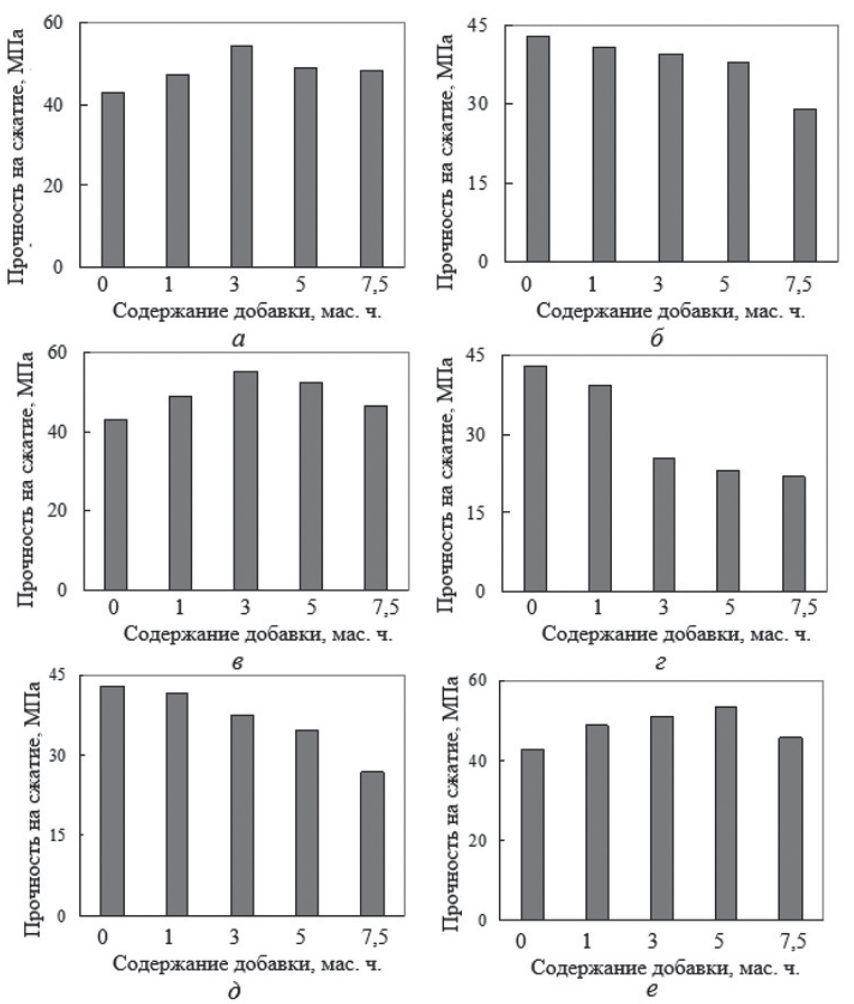

Рис. 2. Зависимость изменения прочности на сжатие цементных композитов от содержания модифицирующих добавок: $a$ - «Тефлекс Антиплесень»; б - «Тефлекс Антисоль смывка»; в - «Тефлекс Реставратор»; г - «Тефлекс Защита для металла»; д - «Тефлекс дезинфицирующий»; е - «Тефлекс индустриальный» центной доверительной вероятности. Это позволило считать уравнения адекватными и принять их за математические модели. По ним построены графические зависимости изменения прочности цементных композитов от количественного содержания и крупности наполнителя в различные сроки твердения (рис. 3).

Полученные результаты свидетельствуют, что для цементных композитов как с добавками, так и контрольных (бездобавочных), максимальные значения прочности достигаются при введении наполнителя крупности 0,315-0,63 мм. Для ряда составов, содержащих 300 и 200 мас. ч. наполнителя на 100 мас. ч. вяжущего, показатель прочности биостойких композитов, модифицированных препаратом «Тефлекс Антиплесень», выше, чем у бездобавочных композитов. Так, для состава, содержащего 300 мас. ч. наполнителя фракции 0,315-0,63 мм, на 28-е сутки увеличение прочности составило $40 \%$.

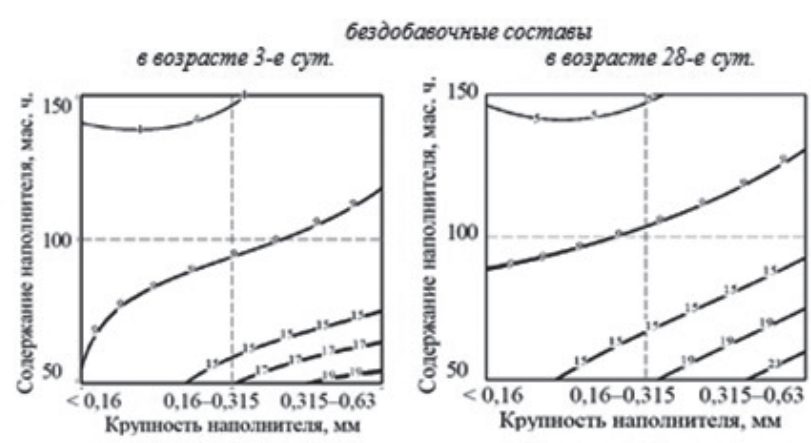

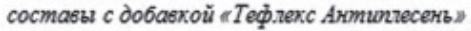
6 6ospacme 3-e cym. 6 6ospacme 28-e cym.
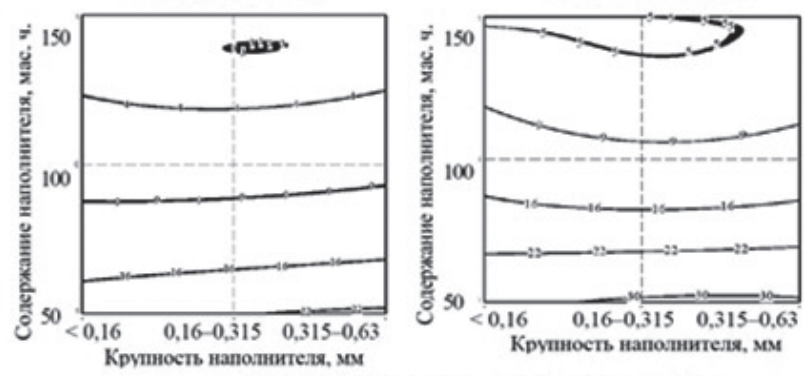

составы $c$ dобавкой «Tеф.лехс дезинфицируточий 6 eospacme 3-e cym. 6 6озрасте 28-e cym.
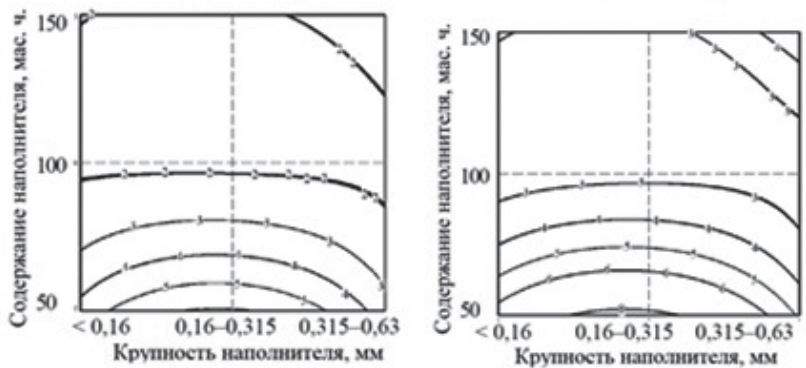

Рис. 3. Зависимость изменения прочности на сжатие цементных композитов в разные сроки твердения от вида добавки, крупности и содержания наполнителя 
Для зданий и сооружений перерабатывающих предприятий, животноводческих и птицеводческих комплексов и т.д. важным является создание здоровых экологических условий в них при отсутствии биологических заражений. Перспективными в этом случае являются трёхслойные конструкции на основе каркасных бетонов [21]. В трёхслойных панелях два крайних слоя выполнены из плотного бетона, а средний - из крупнопористого бетона4. Толщины слоёв можно регулировать в зависимости от теплотехнических требований к зданиям и сооружениям.

Крупнопористая часть трёхслойной конструкции состоит из зёрен заполнителя, склеенных цементным клеем, в котором могут содержаться наполнители различных фракций [21; 22]. Для повышения прочности таких бетонов в клей вводятся наполнители, увеличивающие площадь контакта между зёрнами заполнителя. В этой связи важным является проведение исследования биостойкости клеевых композиций, содержащих кварцевые порошки различных фракций.

Влияние гранулометрического состава кварцевого наполнителя на прочность цементных композитов производилось по симплекс-решетчатому плану Шеффе [23]. Эти планы обеспечивают равномерный разброс экспериментальных точек

4 1. Способ изготовления трехслойной панели. Патент на изобретение RU 2154135.

2. Пол животноводческого помещения. Патент на изобретение RU 2162925.

3. Трехслойный пол свинарника-маточника. Патент на изобретение RU 2150556.

4. Способ изготовления трехслойной панели. Патент на изобретение RU 2219316.
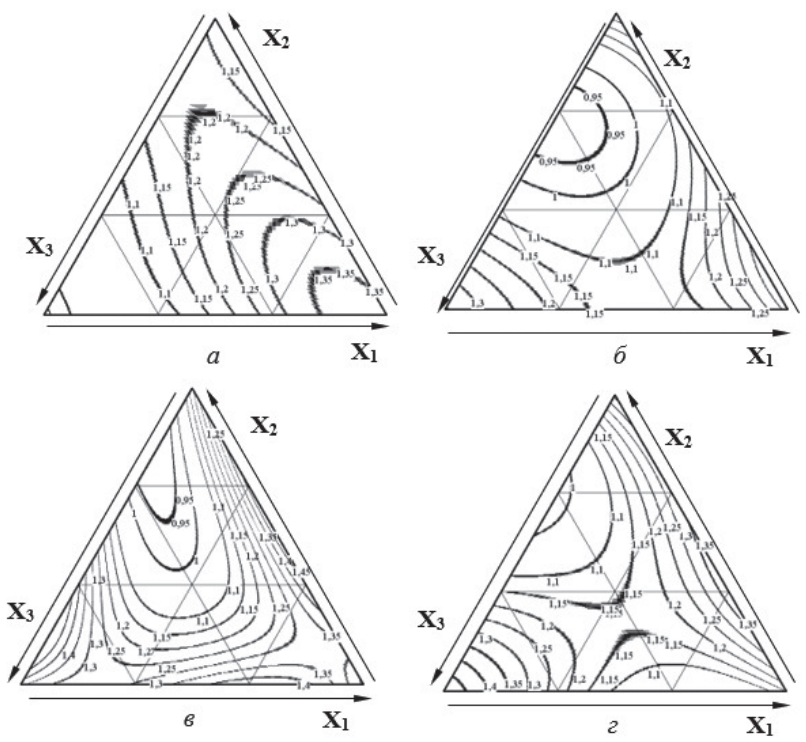

Рис. 4. Зависимость изменения относительной прочности на сжатие цементных композитов от содержания и фракции наполнителя и вида модифицирующей добавки: а) бездобавочный композит; б) модифицированный добавкой «Тефлекс Антиплесень»; в) то же добавкой «Тефлекс Реставратор»; г) то же добавкой «Тефлекс индустриальный» по $(g-1)$-мерному симплексу. Экспериментальные точки представляют $\{g, n\}$ решётку на симплексе, где $g$ - число компонентов смеси; $n$ - степень полинома. Симплекс-решётчатые планы являются насыщенными планами. По каждому компоненту имеется $(n+1)$ одинаково расположенных уровней $x_{\mathrm{i}}=0$, $1 n, 2 / n, \ldots, 1$ и берутся все возможные комбинации с такими значениями концентрации компонентов. В нашем случае для кубической решётки $\{g, 3\}$, обеспечивающей приближение поверхности отклика полинома третьей степени $(n=3)$, должны быть использованы следующие уровни каждого из факторов: $n=3$ (0,..1/3 и 1). Согласно этому, гранулометрический состав молотого кварцевого песка варьировался на трёх уровнях (мм): $X_{1}$ - в интервале от 0,315 до 0,63; $X_{2}$ - в интервале от 0,16 до 0,315; $X_{3}$ - менее 0,16. Содержание наполнителя (мас. ч.) принималось в количествах: 0; 10; 20; и 30 на 100 мас. ч. цемента. Исследованию подвергалась диаграмма «состав свойство» с вершинами $Z_{1}\left(X_{1}=100 \%, X_{2}=0 \%\right) ; Z_{2}\left(X_{2}=100\right.$ $\left.\%, X_{3}=0 \%\right) ; Z_{3}\left(X_{3}=100 \%, X_{1}=0 \%\right)$. Матрица планирования состояла из десяти опытов.

В качестве оптимизируемых факторов рассматривалась прочность на сжатие биостойких модифицированных, а также бездобавочных композитов.

После проведения статистической обработки результатов эксперимента получены уравнения регрессии, связывающие зависимости изменения прочности испытанных композитов различного возраста от рассматриваемых факторов. При проверке адекватности по F-критерию выявлено, что дисперсия адекватности не отличается значимо от дисперсии воспроизводимости, то есть ошибка моделей и ошибка, связанная с точностью эксперимента, на основе которого получены модели, близки к друг другу.

На рисунке 4 приведены графические зависимости изменения прочности биостойких цементных композитов, модифицированных биоцидными добавками, и бездобавочных композитов от количественного содержания и фракции наполнителя, построенные по моделям. Данные взяты на 28-е сутки.

Из графиков видно, что по прочностным показателям все малонаполненные грибостойкие цементные композиты, модифицированные добавкой «Тефлекс Антиплесень» превосходят контрольные ненаполненные составы от 4 до $49 \%$, в зависимости от количественного содержания и фракции наполнителя (кроме состава № 9, состоящего из песка фракций 0,16-0,315 и <0,16 мм в количестве 20 мас. ч. и 10 мас. ч. соответственно).

Полученные результаты дают основание рекомендовать цементные композиции с фунгицидными добавками на основе гуанидина для использования в зданиях с биологическими средами. Эффективность применения цементных композитов с данными биоцидными добавками подкрепляется широкой апробацией разработанных материалов в строительстве как у нас в стране, так и за рубежом. На рисунке 5 а приводятся результаты обследования корейскими специалистами шту- 

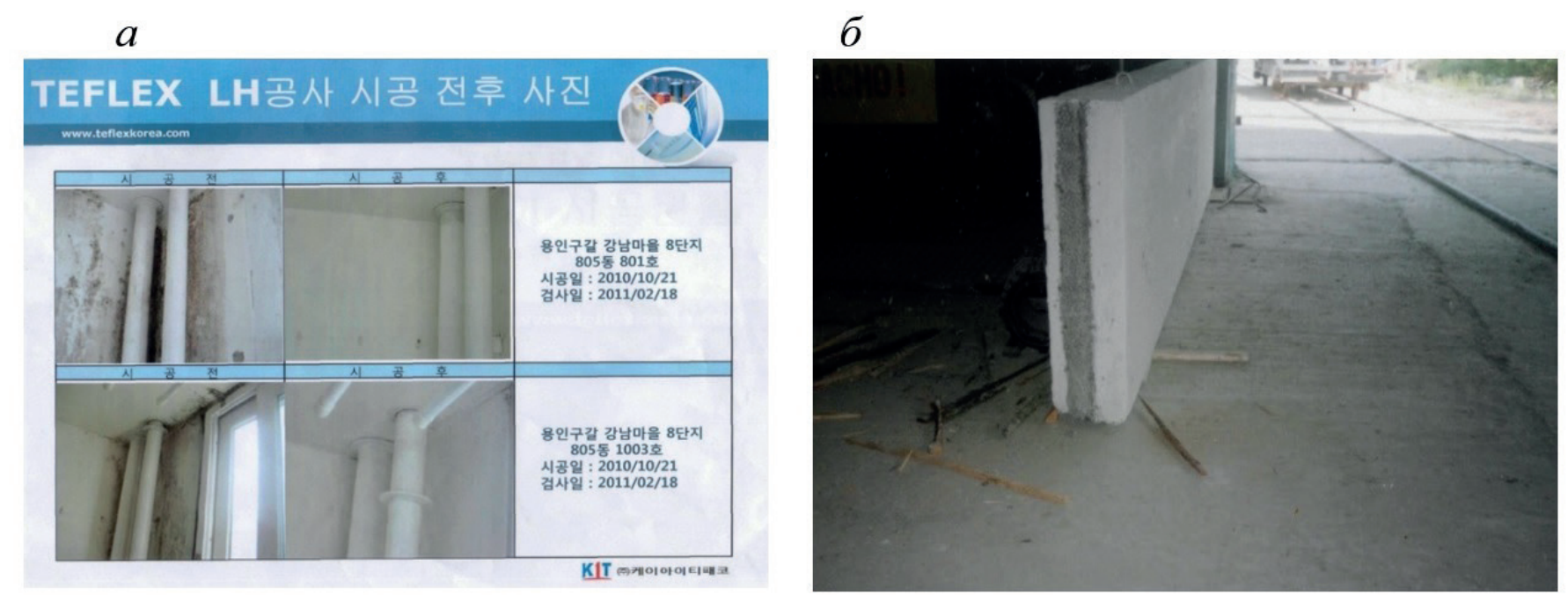

Рис. 5. Результаты обследования штукатурных покрытий, содержащих добавку «Тефлекс» (а) и общий вид стеновой панели (б)

катурных покрытий, содержащих добавку «Тефлекс», а на рисунке 56 - трёхслойные конструкции, выпускаемые АO «Завод ЖБК-1» (Саранск).

Как видно из рисунка 5 а, штукатурные покрытия в сантехкабинах не обрастают микроскопическими грибами, когда в составе растворной композиции присутствуют добавки «Тефлекс». Трёхслойные стеновые панели, обладающие за счёт специфической структуры повышенной биостойкостью и несущей способностью, в настоящее время нашли применение при строительстве животноводческих зданий в Республике Мордовия.

\section{Лuтература}

1. Оценка и прогнозирование физико-химического сопротивления стеклощелочных композитов и методы его повышения / В.Т. Ерофеев, А.П. Федорцов, А.Д. Богатов, В.А. Федорцов // Известия высших учебных заведений. Строительство. - 2017. - № 6 (702). - С. 5-14.

2. 0 современных методах обеспечения долговечности железобетонных конструкций / Н.И. Карпенко, С.Н. Карпенко, В.Н. Ярмаковский, В.Т. Ерофеев // Academia. Архитектура и строительство. - 2015. - № 1. - С. 93-102.

3. Основы математического моделирования биокоррозии полимербетонов / В.Т. Ерофеев, А.П. Федорцов, А.Д. Богатов, В.А. Федорцов // Фундаментальные исследования. - 2014. № 12-4. - С. 701-707.

4. Биокоррозия цементных бетонов, особенности её развития, оценки и прогнозирования / В.Т. Ерофеев, А.П. Федорцов, А.Д. Богатов, В.А. Федорцов // Фундаментальные исследования. - 2014. - № 12-4. - С. 708-716.

5. Исследование механизмов повреждения битумных композитов в условиях воздействия биологических агрессивных сред / В.Т. Ерофеев, А.Д. Богатов, А.П. Федорцов, С.П. Пронькин // Фундаментальные исследования. - 2015. - №2-13. - С. 2787-2800.
6. Соломатов В.И. Биологическое сопротивление полимербетонов / В.И Соломатов., В.Т. Ерофеев, Е.А. Морозов // Строительные материалы. - 2001. - № 7. - С. 10-11.

7. Защита зданий и сооружений от биоповреждений биоцидными препаратами на основе гуанидина / В.Т. Ерофеев, П.Г. Комохов, В.Ф. Смирнов [и др.]. - СПб : Наука, 2010 (2-е издание, исправленное) - 192 с.

8. Строительные материалы на основе отходов стекла / В.Т. Ерофеев, Ю.М. Баженов, А.Д. Богатов. - Саранск : Изд-во Мордов. ун-та, 2005. - 120 с.

9. Комохов П.Г. Золь-гель как концепция нанотехнологии цементного композита, структура системы и пути её реализации / П.Г. Комохов // Вестник БелГТУ им. В.Г. Шухова. - 2007. - № 1. - С. 19-23.

10. Чернышов Е.М. Концепции и основания технологий наномодифицирования структур строительных композитов. Часть 2. К проблеме концептуальных моделей наномодифицирования структуры / Е.М. Чернышов, О.В. Артамонова, Г.С. Славчева // Строительные материалы. - 2014. - № 4. - С. 73-83.

11. Харитонов А.М. Экспериментальное обоснование численных моделей структуры и свойств цементного камня / А.М. Харитонов // Academia. Архитектура и строительство. - 2008. - № 1. - С. 100-103.

12. Баженов Ю.М. Конструирование структур современных бетонов, определяющих принципы и технологические платформы / Ю.М. Баженов, Е.М. Чернышев, Д.Н. Коротких // Строительные материалы. - 2014. - № 3. - С. 6-14.

13. Модифицированные высокопрочные бетоны классов И80 и В90 в монолитных конструкциях / С.С. Каприелов, В.И. Травуш, Н.И. Короленко [и др.] // Строительные материалы. -2008. - №3. - С. 9-13.

14. Калашников В.И. Влияние вида супер- и гиперпластификаторов на реотехнологические свойства цементноминеральных суспензий, порошковых бетонных смесей и 
прочностные свойства бетонов / В.И. Калашников, Е.В. Гуляева, Д.М. Валиев // Известия вузов. Строительство. 2011. - № 12. - С. 40-45.

15. Ушеров-Маршак А.В. Оценка эффективности влияния химических и минеральных добавок на ранние стадии гидратации цементов / А.В. Ушеров-Маршак, 0.А. Златковский, М. Циак // Неорганические материалы. - 2004. - Т. 40. - № 8. - С. 1014-1019.

16. Федорцов А.П. Физико-химическое сопротивление строительных композитов и способы его повышения : монография / А. П. Федорцов. - Саранск : Изд-во Мордовского ун-та, 2015. - 462 с.

17. Горшков В.С. Методы физико-химического анализа вяжущих веществ : учебное пособие для вузов / В.С. Горшков, В.В. Тимашев, В.Г. Савельев. - Москва : Высшая школа, 1981. - 335 C.

18. Сродство структур как теоретическая основа проектирования композитов будущего / В.С. Лесовик, Л.Х. Загороднюк, И.Л. Чулкова // Строительные материалы. - 2015. - № 9. - С. 18-22.

19. Хозин В.Г. Особенности формирования структуры модифицированных песчаных бетонов / В.Г. Хозин, Н.М. Морозов, Х.Г. Мугинов // Строительные материалы. - 2010. -№ 9. - С. 72-73.

20. Кинетика набора прочности биоцидных цементов / А.И. Родин, В.Т Ерофеев., А.П. Пустовгар [и др.] // Вестник МГСУ. - 2014. - № 12. - С. 88-97.

21. Ограждающие конструкции с использованием бетонов низкой теплопроводности (основы теории, методы расчета и технологическое проектирование) / Ю.М. Баженов, Е.А. Король, В.Т. Ерофеев, Е.А. Митина. - М. : АСВ, 2008. - 320 с.

22. Ицкович С.М. Крупнопористый бетон (технология и свойства) / С.М. Ицкович. - М. : Стройиздат, 1977. - 117 с.

23. Ахназарова С.Л. Методы оптимизации эксперимента в химии и химической технологии / С. Л. Ахназарова, В. В. Кафаров. - М. : Высшая школа, 1985. - 327 с.

\section{References}

1. Erofeev V.T., Fedortsov A.P., Bogatov A.D., Fedortsov V.A. Otsenka i prognozirovanie fiziko-khimicheskogo soprotivleniya stekloshchelochnykh kompozitov i metody ego povysheniya [Assessment and forecasting of the physicochemical resistance of glass-alkali composites and methods of its increase]. In: Izvestiya vysshikh uchebnykh zavedenii. Stroitel'stvo [News of Higher Educational Institutions. Construction], 2017, no. 6 (702), pp. 5-14. (In Russ., abstr. in Engl.)

2. Karpenko N.I., Karpenko S.N., Yarmakovskii V.N., Erofeev V.T. 0 sovremennykh metodakh obespecheniya dolgovechnosti zhelezobetonnykh konstruktsii [About modern methods of ensuring the durability of reinforced concrete structures]. In: Academia. Arkhitektura i stroitel'stvo [Academy. Architecture and construction], 2015, no. 1, pp. 93-102. (In Russ., abstr. in Engl.)

3. Erofeev V.T., Fedortsov A.P., Bogatov A.D., Fedortsov V.A. Osnovy matematicheskogo modelirovaniya biokorrozii polimerbetonov [Fundamentals of mathematical modeling of polymer concrete biocorrosion]. In: Fundamental'nye issledovaniya [Fundamental research], 2014, no. 12-4, pp. 701-707. (In Russ.)

4. Erofeev V.T., Fedortsov A.P., Bogatov A.D., Fedortsov V.A. Biokorroziya tsementnykh betonov, osobennosti ee razvitiya, otsenki i prognozirovaniya [Biocorrosion of cement concrete, features of its development, assessment and forecasting]. In: Fundamental'nye issledovaniya [Fundamental research], 2014, no. 12-4, pp. 708-716. (In Russ.)

5. Erofeev V.T., Bogatov A.D., Fedortsov A.P., Pron'kin S.P. Issledovanie mekhanizmov povrezhdeniya bitumnykh kompozitov $v$ usloviyakh vozdeistviya biologicheskikh agressivnykh sred [Investigation of the mechanisms of damage to bitumen composites under the influence of biological aggressive media]. In: Fundamental'nye issledovaniya [Fundamental research], 2015, no. 2-13, pp. 2787-2800. (In Russ.)

6. Solomatov V.I., Erofeev V.T., Morozov E.A. Biologicheskoe soprotivlenie polimerbetonov [Biological resistance of polymer concretes]. In: Stroitel'nye materialy, 2001, no. 7, pp. 10-11. (In Russ., abstr. in Engl.)

7. Erofeev V.T., Komokhov P.G., Smirnov V.F., Svetlov D.A., Kaznacheev S.V., Bogatov A.D., Morozov E.A., Vasil'ev O.D., Makarevich Yu.M., Spirin V.A., Patsyuk N.A. Zashchita zdanii i sooruzhenii ot biopovrezhdenii biotsidnymi preparatami na osnove guanidina [Protection of buildings and structures from biological damage with biocidal preparations based on guanidine]. Saint Petersburg, Nauka Publ., 2010, 192 p.

8. Erofeev V.T., Bazhenov Yu.M., Bogatov A.D., Morozov A.E., Mitina E.A., Korotaev S.A., Kalgin Yu.I., Burnaikin N.F. Stroitel'nye materialy na osnove otkhodov stekla [Construction materials based on glass waste]. Saransk, Publishing house of Mordov. University, 2005, $120 \mathrm{p}$.

9. Komokhov P.G. Zol'-gel' kak kontseptsiya nanotekhnologii tsementnogo kompozita, struktura sistemy i puti ee realizatsii [Sol-gel as a concept of nanotechnology of a cement composite, structure of the system and ways of its implementation]. In: Vestnik BelGTU im. V.G. Shukhova [Bulletin of BSTU named after V.G. Shukhov], 2007, no. 1, pp. 19-23. (In Russ.)

10. Chernyshov E.M., Artamonova O.V., Slavcheva G.S. Kontseptsii i osnovaniya tekhnologii nanomodifitsirovaniya struktur stroitel'nykh kompozitov. Chast' 2. K probleme kontseptual'nykh modelei nanomodifitsirovaniya struktury [Concepts and foundations of technologies for nanomodification of building composite structures. Part 2. On the problem of conceptual models of structure nanomodification]. In: Stroitel'nye materialy, 2014, no. 4, pp. 73-83. (In Russ., abstr. in Engl.)

11. Kharitonov A.M. Eksperimental'noe obosnovanie chislennykh modelei struktury i svoistv tsementnogo kamnya [Experimental substantiation of numerical models of the structure and properties of cement stone]. In: Academia. Arkhitektura i stroitel'stvo [Academia. Architecture and construction], 2008, no. 1, p. 100-103. (In Russ.) 
12. Bazhenov Yu.M. Konstruirovanie struktur sovremennykh betonov, opredelyayushchikh printsipy i tekhnologicheskie platformy [Construction of modern concrete structures, defining principles and technological platforms]. In: Stroitel'nye materialy, 2014, no. 3, pp. 6-14. (In Russ., abstr. in Engl.)

13. Kaprielov S.S., Travush V.I., Korolenko N.I. [et al.] Modifitsirovannye vysokoprochnye betony klassov I80 i V90 v monolitnykh konstruktsiyakh [Modified high-strength concretes of classes I80 and B90 in monolithic structures]. In: Stroitel'nye materialy, 2008, no. 3, pp. 9-13. (In Russ., abstr. in Engl.)

14. Kalashnikov V.I., Gulyaeva E.V., Valiev D.M. Vliyanie vida super- i giperplastifikatorov na reotekhnologicheskie svoistva tsementno-mineral'nykh suspenzii, poroshkovykh betonnykh smesei i prochnostnye svoistva betonov [Influence of the type of super- and hyperplasticizers on rheotechnological properties of cement-mineral suspensions, powder concrete mixtures and strength properties of concretes]. In: Izvestiya vysshikh uchebnykh zavedenii. Stroitel'stvo [News of Higher Educational Institutions. Construction], 2011, no. 12, pp. 40-45. (In Russ., abstr. in Engl.)

15. Usherov-Marshak A.V., Zlatkovskii O.A., Tsiak M. Otsenka effektivnosti vliyaniya khimicheskikh i mineral'nykh dobavok na rannie stadii gidratatsii tsementov [Evaluation of the effectiveness of the influence of chemical and mineral additives on the early stages of hydration of cements]. In: Neorganicheskie materialy [Inorganic Materials], 2004, Vol. 40, no. 8, pp. 1014-1019. (In Russ., in Engl.)

16. Fedortsov A.P. Fiziko-khimicheskoe soprotivlenie stroitel'nykh kompozitov i sposoby ego povysheniya [Physicochemical resistance of building composites and methods of its increase]: monografiya. Saransk, Publishing house of Mordov. University, $462 \mathrm{p}$.
17. Gorshkov V. S. Metody fiziko-khimicheskogo analiza vyazhushchikh veshchestv [Methods of physical and chemical analysis of binders]. Moscow, Vysshaya shkola Publ.., 1981, 335 p.

18. Lesovik V.S., Zagorodnyuk L.Kh., Chulkova I.L., Tolstoi A.D., Volodchenko A.A. Srodstvo struktur kak teoreticheskaya osnova proektirovaniya kompozitov budushchego [The affinity of structures as a theoretical basis for the design of composites of the future]. In: Stroitel'nye materialy, 2015, no. 9, pp. 18-22.

19. Khozin V.G., Morozov N.M., Muginov Kh.G. Osobennosti formirovaniya struktury modifitsirovannykh peschanykh betonov [Features of the formation of the structure of modified sand concretes]. In: Stroitel'nye materialy, 2010, no. 9, pp. 72-73. (In Russ., abstr. in Engl.)

20. Rodin A.I., Erofeev V.T., Pustovgar A.P., Eremin A.V., Pashke-vich S.A., Bogatov A.D., Kaznacheev S.V., Adamtsevich A.0. Kinetika nabora prochnosti biotsidnykh tsementov [Kinetics of strength gain of biocidal cements]. In: Vestnik MGSU, 2014, no. 12, pp. 88-97. (In Russ., abstr. in Engl.)

21. Yu.M. Bazhenov, E.A. Korol', V.T. Erofeev, E.A. Mitina. Ograzhdayushchie konstruktsii s ispol'zovaniem betonov nizkoi teploprovodnosti (osnovy teorii, metody rascheta $i$ tekhnologicheskoe proektirovanie) [Fencing structures using concretes oflow thermal conductivity (fundamentals of theory, calculation methods and technological design)]. Moscow, ASV Publ., 2008, 320 p.

22. Itskovich S.M. Krupnoporistyi beton (tekhnologiya i svoistva) [Coarse-porous concrete (technology and properties)]. Moscow, Stroiizdat Publ., 1977, 117 p.

23. Akhnazarova S. L. Metody optimizatsii eksperimenta $v$ khimii i khimicheskoi tekhnologii [Methods of optimization of experiment in chemistry and chemical technology]. Moscow, Vysshaya shkola, 1985, $327 \mathrm{p}$.

Ерофеев Владимир Трофимович (Саранск). Доктор технических наук, профессор, академик РААСН. Заведующий кафедрой строительных материалов и технологий, декан архитектурно-строительного факультета ФГБОУ В0 «Московский государственный университет им. Н.П. Огарёва» (430000, г. Саранск, Советская, 24. МгУ им. Н.П. Огарёва). Эл почта: yerofeevvt@mail.ru.

Светлов Дмитрий Анатольевич (С.-Петербург). Кандидат технических наук, доцент. Генеральный директор 000 «Софт Протектор» (195030, С.-Петербург, ул. Химиков, дом 28, лит. Ц. Софт-Протектор). Эл. почта: teflex@list.ru.

Смирнов Василий Филиппович (Н. Новгород). Доктор биологических наук, профессор. Заведующий химико-биологическим отделом НИИ химии ФГБОУ В0 «Нижегородский государственный университет» (603022, Н.Новгород, просп. Гагарина, 23, кор. 5. ННГУ им. Н.И.Лобачевского). Эл. почта: biodeg@mail.ru.

Федорцов Анатолий Петрович (Саранск). Кандидат технических наук, доцент. Доцент кафедры строительных материалов и технологий ФГБОУ В0 «Московский государственный университет им. Н.П. Огарёва» (430000, г. Саранск, Советская, 24. МГУ им. Н.П. Огарёва). Эл почта: fedorcovap@mail.ru.

Казначеев Сергей Валерьевич (Саранск). Кандидат технических наук, доцент. Доцент кафедры строительных материалов и технологий ФГБОУ В0 «Московский государственный университет им. Н.П. Огарёва» (430000, г. Саранск, Советская, 24. МгУ им. Н.П. Огарёва). Эл почта: kaznacheevsv@mail.ru. 
Богатов Андрей Дмитриевич (Саранск). Кандидат технических наук, доцент. Доцент кафедры строительных материалов и технологий ФГБОУ В0 «Московский государственный университет им. Н.П. Огарёва» (430000, г. Саранск, Советская, 24. МгУ им. Н.П. Огарёва). Эл почта: bogatovad@list.ru.

Родин Александр Иванович (Саранск). Кандидат технических наук, доцент. Доцент кафедры строительных материалов и технологий ФГБОУ В0 «Московский государственный университет им. Н.П. Огарёва» (430000, г. Саранск, Советская, 24. Мгу им. Н.П. Огарёва). Эл почта: AL_Rodin@mail.ru.

Краева Людмила Александровна (С.-Петербург). Доктор медицинских наук, доцент. Заведующая лабораторией медицинской бактериологии ФБУН «НИИ эпидемиологии и микробиологии имени Пастера» (197101, Санкт-Петербург, ул. Мира, д. 14. НИИЭМ имени Пастера), профессор кафедры микробиологии Военно-медицинской академии им. С.М. Кирова. Эл. почта: lykraeva@yandex.ru.

Erofeev, Vladimir T. (Saransk). Doctor of Technical Sciences, Professor, Academician of RAACS. Head of the Department of Building Materials and Technologies, Dean of the Faculty of Architecture and Construction Engineering at the Ogarev Mordovia State University (24 Sovetskaya Str., Saransk, 430000. MRSU). E-mail: yerofeevvt@mail.ru.

Svetlov Dmitry A. (Saint Petersburg). Candidate of Technical Sciences, Associate Professor. General Director of 000 "SoftProtector" (28 Khimikov Str., St. Petersburg, 195030. Soft Protector). E-mail: teflex@list.ru.

Smirnov Vasily F. (N. Novgorod). Doctor of Biological Sciences, Professor. Head of the Chemical and Biological Department of Research Institute of Chemistry of Nizhny Novgorod State University (603022, N. Novgorod, 23 Gagarina Ave., Building 5. UNN named after N.I. Lobachevsky).E-mail: biodeg@mail.ru.

Fedortsov Anatoly P. (Saransk). Candidate of Technical Sciences, Associate Professor. Associate Professor of the Department of Building Materials and Technologies, Ogarev Mordovia State University (24 Sovetskaya Str., Saransk, 430000. MRSU). E-mail: fedorcovap@mail.ru.

Kaznacheev Sergey V. (Saransk). Candidate of Technical Sciences, Associate Professor. Associate Professor of the Department of Building Materials and Technologies, Ogarev Mordovia State University (24 Sovetskaya Str., Saransk, 430000. MRSU). E-mail: kaznacheevsv@mail.ru.

Bogatov Andrey D. (Saransk). Candidate of Technical Sciences, Associate Professor. Associate Professor of the Department of Building Materials and Technologies, Ogarev Mordovia State University (24 Sovetskaya Str., Saransk, 430000. MRSU). E-mail: bogatovad@list.ru.

Rodin Alexander I. (Saransk). Candidate of Technical Sciences, Associate Professor. Associate Professor of the Department of Building Materials and Technologies, Ogarev Mordovia State University (24 Sovetskaya Str., Saransk, 430000. MRSU). E-mail: AL_Rodin@mail.ru.

Kraeva Lyudmila A. (Saint Petersburg). Doctor of Medical Sciences, Associate Professor. Head of the Laboratory of Medical Bacteriology of the Pasteur Research Institute of Epidemiology and Microbiology (14, Mira str., St Petersburg, 197101. Pasteur Institute), Professor of the Department of Microbiology at the S.M. Kirov Military Medical Academy. E-mail:lykraeva@yandex.ru. 